mine receptor (D3) as a target for neuroleptics. Nature 1990; 347:146-151.

37. Pierot L, Desnos C, Blin J, et al. D1 and D2-type dopamine receptors in patients with Parkinson's disease and progressive supranuclear palsy. J Neurol Sci 1988;86:291-306.

38. Rinne JO, Laihinen A, Lönnberg P, Marjamäki P, Rinne UK. A postmortem study on striatal dopamine receptors in Parkinson's disease. Brain Res 1991;556:117-122.

39. Gurevich EV, Joyce JN. Distribution of dopamine D3 receptor expressing neurons in the human forebrain: comparison with D2 receptor expressing neurons. Neuropsychopharmacology 1999;20:60-80.

40. Dooley M, Markham A. Pramipexole. A review of its use in the management of early and advanced Parkinson's disease. Drugs Aging 1998;12:495-514.

41. Antonini A, Schwarz J, Oertel WH, Beer HF, Madeja UD, Leenders $\mathrm{KL}$. $\left[{ }^{11} \mathrm{C}\right]$ Raclopride and positron emission tomography in previously untreated patients with Parkinson's disease: influence of L-dopa and lisuride therapy on striatal dopamine D2-receptors. Neurology 1994;44:1325-1329.

42. Herrero MT, Augood SJ, Asensi H, et al. Effects of L-DOPA therapy on dopamine D2 receptor mRNA expression in the striatum of MPTP-intoxicated parkinsonian monkeys. Brain Res Mol Brain Res 1996;42:149-155.

43. Morissette M, Goulet M, Calon F, et al. Changes of D1 and D2 dopamine receptor mRNA in the brains of monkeys lesioned with 1-methyl-4-phenyl-1,2,3,6-tetrahydropyridine: correction with chronic administration of L-3,4-dihydroxyphenylalanine. Mol Pharmacol 1996;50:1073-1079.
44. Bordet R, Ridray S, Carboni S, Diaz J, Sokoloff P, Schwartz JC. Induction of D3 receptor expression as a mechanism of behavioral sensitization to levodopa. Proc Natl Acad Sci 1997; 94:3363-3367.

45. Tamaru F. Disturbances in higher function in Parkinson's disease. Eur Neurol 1997;38(suppl 2):33-36.

46. Weinberger DR, Berman KF, Chase TN. Mesocortical dopaminergic function and human cognition. Ann NY Acad Sci 1988; 537:330-338.

47. Ring HA, Bench CJ, Trimble MR, Brooks DJ, Frackowiak RS, Dolan RJ. Depression in Parkinson's disease. A positron emission study. Br J Psychiatry 1994;165:333-339.

48. Grossman M, Crino P, Reivich M, Stern MB, Hurtig HI. Attention and sentence processing deficits in Parkinson's disease: the role of anterior cingulate cortex. Cereb Cortex 1992; 2:513-525.

49. Ribeyre JM, Lesieur P, Varoquaux O, Dollfus S, Pays M, Petit M. A comparison of plasma homovanillic acid in the deficit and nondeficit subtypes of schizophrenia. Biol Psychiatry 1994;36:230-236.

50. Farde L, Gustavsson JP, Jönsson E. D2 dopamine receptors and personality traits. Nature 1997;385:590.

51. Alexander GE, Delong MR, Strick PL. Parallel organization of functionally segregated circuits linking basal ganglia and cortex. Annu Rev Neurosci 1986;9:357-381.

52. Joyce JN, Goldsmith SG, Gurevich EV. Limbic circuits and monoamine receptors: dissecting the effects of antipsychotics from disease processes. J Psychiatr Res 1997;31:197-217.

\title{
Neuro/mages
}
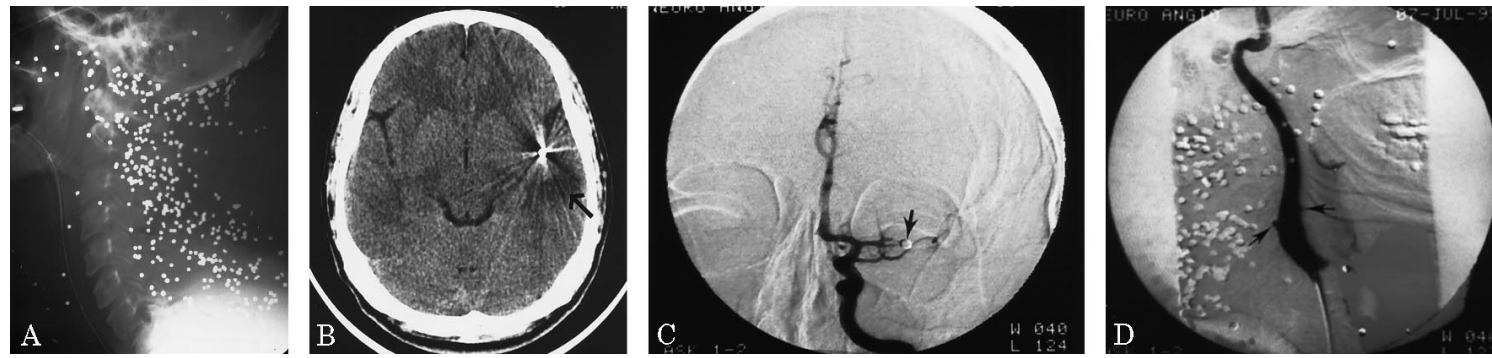

Figure. (A) Lateral X-ray of the neck shows numerous pellets. (B) Unenhanced transaxial CT shows an intracranial pellet without evidence of skull or parenchymal lesions to account for pellet entry pathway. The arrow points to the area of infarction, which extends superiorly. (C) Anteroposterior view of the cerebral angiogram shows a pellet (arrow) in the left middle cerebral artery. (D) Oblique lateral projection of the angiogram shows two small pseudoaneurysms (arrows) in proximal left internal carotid artery, indicative of pellet entry site.

\section{Cerebral shotgun pellet embolism}

Roy Yaari, Jamshid Ahmadi, MD,

Gregory Youngnam Chang, $M D$,

Los Angeles, CA

A 40-year-old man sustained a shotgun wound to the neck. The next day he was aphasic with right hemiparesis. A head CT showed a pellet in the left sylvian fissure without overlying bony defect. An angiogram confirmed the pellet in the left middle cerebral artery without contrast extravasation from the left cervical carotid artery. A repeat angiogram 12 days later showed a pseudoaneurysm in the left proximal internal carotid artery, indicative of a pellet entry site. The third angiogram 1 month later demonstrated an unchanged pseudoaneurysm. The right hemiparesis resolved; however, the aphasia remained.
Shotgun wounds with multiple metal pellets in the neck may result in a delayed pellet embolism to the intracranial vessels. ${ }^{1}$ Owing to the small size of these missiles, direct puncture through the cervical carotid artery wall may not result in angiographic dye leakage on initial evaluation. Follow-up angiogram may reveal a pseudoaneurysm in nearly $50 \%$ of cases. ${ }^{2}$ The majority of these pseudoaneurysms will heal spontaneously and are best managed by observation and serial angiograms if indicated.

1. van As AB, Pillay R, Domingo Z. Shotgun pellet embolus to the anterior cerebral artery. Injury 1995;26:631-632.

2. Stain SC, Yellin AE, Weaver FA, Pentecost MJ. Selective management of nonocclusive arterial injuries. Arch Surg 1989;124:1136-1141. 


\section{Neurology}

\section{Cerebral shotgun pellet embolism}

Neurology 2000;54;1487

DOI 10.1212/WNL.54.7.1487

This information is current as of April 11, 2000

\section{Updated Information \&}

Services

Permissions \& Licensing

Reprints including high resolution figures, can be found at: http://n.neurology.org/content/54/7/1487.full

Information about reproducing this article in parts (figures,tables) or in its entirety can be found online at:

http://www.neurology.org/about/about_the_journal\#permissions

Information about ordering reprints can be found online:

http://n.neurology.org/subscribers/advertise

Neurology ${ }^{\circledR}$ is the official journal of the American Academy of Neurology. Published continuously since 1951, it is now a weekly with 48 issues per year. Copyright . All rights reserved. Print ISSN: 0028-3878. Online ISSN: 1526-632X.

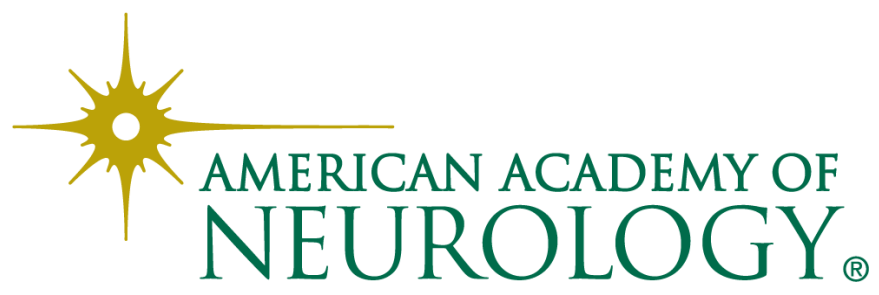

